* Mestranda em Direito Ambiental e Desenvolvimento Sustentável na Escola Superior Dom Helder Câmara. Especialista em Direito e Processo do Trabalho pela PUCMINAS. Graduada em Direito pela Universidade Salgado de Oliveira (2010) e e graduada em Matemática pela Universidade Federal de Minas Gerais (1999). Atualmente é professora da FACSAL Faculdade de Santa Luzia. Experiência na área de Direito, com ênfase em Direito do Trabalho. E-mail: daniog71@yahoo.com

** Mestre e Doutor em Direito. Coordenador e Professor do Programa de PósGraduação em Direito da Escola Superior Dom Helder C â $\mathrm{m}$ a r a . E - m a i 1 : elcio@domhelder.edu.br

\section{Responsabilidade Civil Ambiental na Alemanha: um estudo comparativo com o direito brasileiro}

\section{Civil Liability in Germany: a Comparative STUDY WITH BRAZILIAN LAW}

\author{
* Daniela Oliveira Gonçalves \\ ** Élcio Nacur Rezende
}

Resumo: Buscando comparar os institutos de responsabilidade civil ambiental daAlemanha com os do Brasil, o presente estudo pretende realizar uma análise da responsabilidade civil por danos ambientais naAlemanha. Inicialmente são analisados os conceitos da responsabilidade civil e suas espécies, subjetiva e objetiva. Em seguida o conceito de responsabilidade civil por danos ambientais na legislação brasileira é analisado, discutindo também o conceito de dano ambiental. Finalmente é realizada a apreciação de alguns dispositivos do Código CivilAlemão e também a Lei de Responsabilidade CivilAmbiental daAlemanha.

Palavras-chave: Alemanha. Dano Ambiental. Responsabilidade Civil.

Abstract: The present study aims to conduct a brief analysis of civil liability for environmental damage in Germany. Initially the concepts of liability and its species, subjective and objective are analyzed. Then analyzes the concept of civil liability for environmental damage in Brazilian legislation, also discussing the concept of environmental damage. Is then performed an analysis of some articles of the German Civil Code and also the Environmental Liability Act of Germany.

Keywords: Germany. Environmental Damage. Liability 


\section{INTRODUÇÃO}

A preservação do meio ambiente tem grande importância para a manutenção da vida saudável para todos os seres vivos. O que se pretende, com as normas ambientais é a prevenção de danos ao meio ambiente. Ocorre que nem sempre é possível evitar a ocorrência do dano ambiental e é necessário então que os causadores do impacto sejam responsabilizados.

A responsabilidade por danos causados ao meio ambiente existe no mundo inteiro. A responsabilização por danos ambientais possui grande importância para a recuperação do meio ambiente, através da imposição de obrigações de reparação e/ou indenização pelos danos ambientais causadosA responsabilidade civil possui também função preventiva, na medida em que a certeza da imposição de sanções civis exerce uma função educativa, limitando ou evitando a ocorrência de danos ambientais. No Brasil está prevista na Constituição Federal, no Código Civil e em normas ambientais, com destaque especial para a Lei $n^{0} 6.938 / 81$ que instituiu a Política Nacional do MeioAmbiente

O presente trabalho tem por objetivo realizar um resgate dos conceitos básicos acerca da responsabilidade civil, suas espécies (responsabilidade subjetiva e objetiva) e a responsabilidade civil ambiental. Em seguida, busca-se a definição de dano ambiental para finalmente, realizar uma pesquisa sobre a responsabilidade civil ambiental naAlemanha, através da análise de normas do Código CivilAlemão e da Lei de Responsabilidade CivilAmbiental.

\section{ARESPONSABILIDADE CIVIL}

\subsection{Breve evolução histórica}

A responsabilidade pode ser definida como a obrigação de responder pelos seus atos ou por atos de outrem. Fundamenta-se no dever de não prejudicar o outro. Segundo Rui Stoco,

A noção da responsabilidade pode ser haurida da própria origem da palavra, que vem do latimrespondere, responder a alguma coisa, ou seja, a necessidade que existe de responsabilizar alguém pelos seus atos danosos. Essa imposição estabelecida pelo meio social regrado, através dos integrantes da sociedade humana, de impor a todos o dever de responder por seus atos, traduz a própria noção de justiça existente no grupo social estratificado. Revela-se, pois, como algo inarredável da natureza humana'(STOCO, 2011, p.135). 
Nas sociedades mais primitivas, onde as relações sociais eram reguladas pelos costumes, a reação às lesões sofridas era imediata e praticada pelo próprio ofendido. Segundo Maria Helena Diniz (2013, p. 26-31), nos primórdios existia a vingança coletiva, na qual todo o grupo reagia contra o agressoPosteriormente o homem passou a fazer justiça com as próprias mãos, de forma individuaAos poucos o Estado começou a intervir inicialmente apenas limitando a forma da vingança privada, para em seguida impedir a vingança e determinar a forma de composição dos conflitos. A Lex Aquilia de dammo consolidou a idéia de reparação pecuniária do dano, tendo por base a culpa do causador do prejuízo.

Na Idade Média, as noções de dolo e culpa se desenvolveram e a responsabilidade civil se distinguiu da penal. Com o passar do tempo, o conceito de responsabilidade civil sofreu alterações em relação ao fundamento (evoluindo da responsabilidade subjetiva para a objetiva), aos responsáveis pelos danos (solidariedade entre os causadores de danos) e à profundidade da indenização (atualmente o patrimônio do causador do dano responde por todos os danos causados).

\subsection{Conceito de responsabilidade}

A responsabilidade tem sua origem no dano causado a outrem e na sua reparação. Para Cavalieri Filho,

Em seu sentido etimológico, responsabilidade exprime a idéia de obrigação, encargo, contraprestação. Em sentido jurídico, o vocábulo não foge dessa idéia. Designa o dever que alguém tem de reparar prejuízo decorrente da violação de um outro dever jurídico. (CAALIERI FILHO, 2010. p.2 )

Já Maria Helena Diniz conceitua responsabilidade civil como

[...] a aplicação de medidas que obriguem alguém a reparar dano moral ou patrimonial causado a terceiros, em razão de ato do próprio imputado, de pessoa por quem ele responde ou de fato de coisa ou animal sob sua guarda, ou ainda de simples imposição legal. (DINIZ, 2013, p.50)

Segundo Carlos de Souza, "responsabilidade deriva etimologicamente do latim responsus, do verbo respondere (responder, afiançar, prometer, pagar). Que transmite a idéia de alguém reparar, recuperar, compensar ou pagar pelo que fez" (SOUZA, 2008, p.118). 
O Código Civil de 2002, em seu artigo 927, prevê a responsabilidade civil subjetiva, nos seguintes termos:

Art. 927. Aquele que, por ato ilícito (arts. 186 e 187), causar dano a outrem, fica obrigado a repará-lo.

Parágrafo único. Haverá obrigação de reparar o dano, independentemente de culpa, nos casos especificados em lei, ou quando a atividade normalmente desenvolvida pelo autor do dano implicar, por sua natureza, risco para os direitos de outrem.

A responsabilidade Civil pode ser classificada sob várias espécies. Importa para este estudo a classificação quanto ao fundamentoAssim, a responsabilidade pode ser subjetiva, quando depende da comprovação da culpa do agente, ou objetiva, quando se baseia na teoria do risco.

\subsection{Responsabilidade Subjetiva}

O Direito Civil Brasileiro adota, como regra, a responsabilidade civil subjetiva, na qual a responsabilidade decorre do ato ilícito que cause dano a outrem. Dessa forma, é possível concluir que a norma exige, em regra geral, a ocorrência simultânea de três requisitos: o ato ilícito, o dano e o nexo causal.

$\mathrm{O}$ ato ilícito se caracteriza como a conduta humana que viola uma norma jurídica, conforme estabelece o Código Civil em seus artigos 186 a 188:

Art. 186. Aquele que, por ação ou omissão voluntária, negligência ou imprudência, violar direito e causar dano a outrem, ainda que exclusivamente moral, comete ato ilícito.

Art. 187. Também comete ato ilícito o titular de um direito que, ao exercê-lo, excede manifestamente os limites impostos pelo seu fim econômico ou social, pela boa-fé ou pelos bons costumes.

Art. 188. Não constituem atos ilícitos:

I - os praticados em legítima defesa ou no exercício regular de um direito reconhecido;

II - a deterioração ou destruição da coisa alheia, ou a lesão a pessoa, a fim de remover perigo iminente.

Parágrafo único. No caso do inciso II, o ato será legítimo somente quando as circunstâncias o tornarem absolutamente necessário, não excedendo os limites do indispensável para a remoção do perigo. 
Dessa forma, verifica-se que o ato ilícito consiste em uma ação ou omissão humana relevantes para o Direito. Para Cavalieri Filho (2010, p. 9), a ilicitude possui dois aspectos: o aspecto objetivo, que "leva em conta para a configuração da ilicitude apenas a conduta ou fato em si mesmo, sua materialidade ou exterioridade, e verifica-se a desconformidade dela com a que o Direito queria." Já no seu aspecto subjetivo, "a qualificação de uma conduta como ilícita implica fazer um juízo de valor a seu respeito - o que só é possível se tal conduta resultar de ato humano consciente e livre".

O dano é caracterizado quando há uma lesão sofrida pela vítima, em qualquer de seus direitos. Rui Stoco (2007, p.128), ao falar sobre o dano assim se posiciona: "O dano é, pois, elemento essencial e indispensável à responsabilização do agente, seja essa obrigação originada de ato ilícito ou de inadimplemento contratual, independente, ainda, de se tratar de responsabilidade objetiva ou subjetiva."

Cavalieri Filho (2010, p. 73), afirma que o dano pode ser patrimonial ou moral, assim conceituando o dano patrimonial: "O dano patrimonial, também chamado de dano material, atinge os bens integrantes do patrimônio da vítima, entendendo-se como tal o conjunto de relações jurídicas de uma pessoa apreciáveis economicamente".

Já o dano moral é assim definido por Carlos Roberto Gonçalves:

Dano moral é o que atinge o ofendido como pessoa, não lesando seu patrimônio. É lesão de bem que integra os direitos da personalidade, como a honra, a dignidade, intimidade, a imagem, o bom nome, etc., como se infere dos art. $1^{\circ}$, III, e $5^{\circ}, \mathrm{V}$ e X, da Constituição Federal, e que acarreta ao lesado dor, sofrimento, tristeza, vexame e humilhação (GONÇAVES, 2008, p. 359).

Ainda falando sobre o dano, PauloAffonso Leme Machado (2009, p.351) afirma que

Não se aprecia subjetivamente a conduta do poluidor, mas a ocorrência do resultado prejudicial ao homem, seu ambiente. (...)

A atividade poluente acaba sendo uma apropriação pelo poluidor dos direitos de outrem, pois na realidade a emissão de poluente representa um confisco do direito de alguém em respirar ar puro, beber água saudável e viver com tranquilidade. (MACHADO, 2009, P. 351)

O terceiro requisito é o nexo causal, que é definido por Cavalieri Filho nos seguintes termos: 
O conceito de nexo causal nã o é exclusivamente jurídico; decorre primeiramente das leis naturais. É o vínculo, a ligação ou relação de causa e efeito entre a conduta e o resultado. A relação causal estabelece vínculo entre um determinado comportamento a um evento. (...) Mas o nexo causal, além desse elemento naturalístico, exige também uma avaliação jurídica pelo juiz para verificar, com precisão, a relação entre certo fato e determinado resultado. É um processo técnico de probabilidade. (...) em suma, o nexo causal é um elemento referencial entre a conduta e o resultado. É um conceito jurídico-normativo através do qual poderemos concluir quem foi o causado do dano. (CAVALIERI FILHO, 2010, p.47)

Referido requisito, acima definido, está também contextualizado na responsabilidade objetiva, cuja discussão será feita a seguir

\subsection{Responsabilidade objetiva}

Na responsabilidade objetiva, os requisitos do dano e do nexo causal são exigidos, sendo dispensada apenas a verificação da conduta culposa. Existem na legislação brasileira, várias hipóteses em que a responsabilidade civil será objetiva, porém permanece sendo exceção à regra, aplicável somente nas hipóteses previstas no ordenamento jurídico.

Segundo Cavalieri Filho (2010, p.140), na responsabilidade objetiva "só não será necessário o elemento culpa, razão pela qual fala-se em responsabilidade independentemente de culpa. Essa pode ou não existir , mas será sempre irrelevante para a configuração do dever de indenizar"

Ainda segundo o autor a responsabilidade objetiva se baseia na teoria do risco, sendo que "risco é perigo, é probabilidade de dano, importando, isso, dizer que aquele que exerce uma atividade perigosa deve-lhe assumir os riscos e reparar o dano dela decorrente" (CAVALIERI FILHO, 2010, p. 142)

Várias concepções surgiram em torno da teoria do risco, mas para o presente estudo interessam apenas as teorias do risco criado e do risco integral. A teoria do risco criado determina que aquele que desenvolve uma atividade deve responder pelos danos que essa atividade causarporque assume os riscos a ela inerentes. Nessa modalidade de responsabilidade, o empreendedor pode excluir sua responsabilidade se comprovar, por exemplo, força maior ou culpa exclusiva da vítima.

Pela teoria do risco criado, segundo Caio Mário (1992, p.24), “aquele que, em razão de sua atividade ou profissão, cria um perigo, está sujeito à 
reparação do dano que causar, salvo prova de haver adotado todas as medidas idôneas a evitá-lo."

Segundo Karina Bedran e Elizabeth Mayer (2013, p. 53),

A teoria do risco criado fundamenta-se na característica da sociedade de risco contemporânea. Onde as atividades desenvolvidas, tanto as perigosas como uma atividade qualquer podem levar à responsabilização caso causem danos. (...) A base da responsabilidade pelo risco é qualquer atividade desenvolvida.

Ainda sobre a teoria do risco criado, Rui S toco (2011, p. 189) entende que o agente "responde em razão do risco ou perigo que a atividade exercida apresenta, ou seja, aquele que em razão de sua atividade ou profissão cria um perigo ou expõe alguém a risco de dano"

Já a teoria do risco integral determina que a responsabilidade decorre da própria atividade e as excludentes de responsabilidade não são admitidas. Para Cavalieri Filho (2010, p. 145), “o dever de indenizar se faz presente tão só em face do dano, ainda nos casos de culpa exclusiva da vítima, fato de terceiro, caso fortuito ou de força maior".

Para Steigleder (2011, p. 173-174), no Brasil utiliza-se a teoria do risco integral, segundo a qual "a criação de um risco seria suficiente para a imputação, sem exigência de se comprovar que a atividade guarda adequação causal de conformidade com o dano ou possui vínculo direto com este". (STEIGLEDER, 2011, p. 173-174)

Segundo Carlos de Souza (2008, p.122), “como consequência objetiva da responsabilidade civil fundada na Teoria do Risco integral é prescindível a investigação de culpa; é irrelevante a licitude da atividade; e não se aplicam excludentes ou a cláusula de não indenizar."

\section{ARESPONSABILIDADE CIVILAMBIENTAL}

Atualmente a questão ambiental é um tema presente em todas as áreas de conhecimento e especialmente em todas as áreas do direito. O desenvolvimento tecnológico e econômico mantém um ritmo acelerado, o que acaba por provocar vários danos ao meio ambiente. Com o desenvolvimento da legislação ambiental, a responsabilidade civil por danos ambientais representa um importante instrumento de preservação ambiental. Através deste instituto jurídico, que se baseia nos princípios da prevenção e dpoluidor-pagador, aquele 
que degradou o meio ambiente é obrigado a reparar o dano e a indenizar os danos decorrentes dele. Antes mesmo da atual Constituição Federal, a recepcionada lei que instituiu a Política Nacional do MeiøAmbiente, Lei 6.938, de 1981 , estabelecia, em seu artigo $14, \S 1^{\circ}$, a responsabilidade civil objetiva para os causadores de dano ambiental, nos seguintes termos:

Art. $14(\ldots)$

$\S 1^{\circ} \mathrm{Sem}$ obstar a aplicação das penalidades previstas neste artigo, é o poluidor obrigado, independentemente da existência de culpa, a indenizar ou reparar os danos causados ao meio ambiente e a terceiros, afetados por sua atividade. O Ministério Público da União e dos Estados terá legitimidade para propor ação de responsabilidade civil e criminal, por danos causados ao meio ambiente.

O referido artigo foi recepcionado pela Constituição Federal de 1988, que também prevê, no $\S 3^{\circ}$ do artigo 225 , responsabilidade aos causadores de dano ao meio ambiente. Segundo Cavalieri Filho (2010, p.154), da análise das previsões legais é possível concluir que a responsabilidade por danos ambientais é objetiva, fundamentada na teoria do risco integral.

Segundo Steigleder, a responsabilidade civil ambiental é objetiva e

Tem como pressuposto a existência de uma atividade que implique riscos para a saúde e para o meio ambiente, impondo-se ao empreendedor a obrigação de prevenir tais riscos (princípio da prevenção) e de internalizálos em seu processo produtivo (princípio do poluidor-pagador). Pressupõe ainda, o dano ou risco de dano e o nexo de causalidade entre a atividade e o resultado, efetivo ou pdencial. (STEIGLEDER, 2011, p. 171)

De acordo com Annelise M. S teigleder, alguns princípios ambientais interligam-se com a responsabilidade civil ambiental e definem suas funções. São os princípios da solidariedade com o futuro, da precaução e da prevenção e do poluidor-pagador. Segundo a autora, com o princípio da solidariedade com o futuro:

[...] amplia-se a função da responsabilidade civil que deve responder satisfatoriamente à necessidade de reparar os danos ambientais a fim de que as gerações futuras possam usufruir, pelo menos, da mesma quantidade de que dispomos hoje. [...] 
Assim, a geração presente torna-se guardiã da natureza e das gerações futuras, cujos interesses estão indissociavelmente confundidos. (STEIGLEDER, 2011, p.160)

Já os princípios da precaução e da prevenção, que tê $m$ por objetivo a implementação de medidas protetivas ao meio ambiente, de forma a evitar ou mitigar danos. Segundo Paulo Afonso Leme Machado:

A precaução age no presente para não se ter que chorar e lastimar o futuro. A precaução não só deve estar presente para impedir o prejuízo ambiental, mesmo incerto, que possa resultar das ações ou omissões humanas, como deve atuar para a prevenção oportuna desse prejuízo. Evita-se o dano ambiental através da prevenção no tempo certo. (MACHADO, 2001, p. 57).

No que diz respeito ao princípio do poluidor pagadorassim se posiciona o Ministro do Superior Tribunal de Justiça, Antônio Herman de Vasconcelos e Benjamin:

O objetivo maior do princípio poluidor-pagador é fazer com que os custos das medidas de proteção do meio-ambiente — as externalidades ambientais - repercutam nos custos finais de produtos e serviços cuja produção esteja na origem da atividade poluidora. (BENJAMIN, 1993, p.4)

Segundo Carlos de Souza,

A responsabilidade civil ambiental segue três princípios básicos: da prevenção, do poluidor-pagador, da reparação integral e seus pressupostos são o evento danoso e o nexo de causalidade.

A ação reparatória por dano ambiental, coletiva ou individual, obedece ao sistema de responsabilidade objetiva, fundada no risco próprio de qualquer atividade. (SOUZA, 2008, p. 121-122)

A responsabilidade civil ambiental, dessa forma, tem por objetivo não apenas recuperar o meio ambiente e reparar os danos, mas também punir os poluidores e prevenir novos danos, desencorajando os atos danosos ao meio ambiente. 


\section{O DANO AMBIENTAL}

O dano ambiental e suas consequências ocupam atualmente um lugar de destaque nas discussões jurídicas. No mundo inteiro é possível perceber a preocupação das nações com o desenvolvimento sustentável e a preservação ambiental. O meio ambiente recebe proteção internacional, através de tratados e documentos decorrentes das Conferências das Nações Unidas sobre o Meio Ambiente, tais como a Declaração de Estocolmo, a Agenda 21, a Convenção sobre Diversidade Biológica, a Convenção sobre Mudanças Climáticas, dentre tantos outros.

Também as nações, em seus ordenamentos internos, se preocupam com a proteção ambiental e publicam normas para garantir a preservação do Meio Ambiente. No Brasil, a Constituição Federal, em seu artigo 225 determina:

Art. 225: Todos têm direito ao meio ambiente ecologicamente equilibrado, bem de uso comum do povo e essencial à sadia qualidade de vida, impondose ao Poder Público e à coletividade o dever de defendê-lo e preservá-lo para as presentes e futuras gerações. [...]

Além da Constituição Federal, várias outras normas se preocupam com a proteção ambiental, tais como a Lei da Política Nacional do MeioAmbiente, o Código Florestal, a Lei de CrimesAmbientais, dentre outros.

Em nosso ordenamento jurídico o conceito legal de meio ambiente pode ser encontrado no artigo $3^{\circ}$, inciso I da Lei 6.938/81 - Lei da Política Nacional do Meio Ambiente, sendo definido como: "o conjunto de condições, leis influências e interações de ordem física, química e biológica, que permite, abriga e rege a vida em todas as suas formas"

Comentando o conceito legal,Annelise Steigleder afirma que:

[...] trata-se de conceito sistêmico que visualiza o meio ambiente como uma unidade inter-relacionada, integrada pela natureza original, artificial e pelos bens culturais, pressupondo-se uma interdependência entre todos os elementos que integram o conceito, inclusive o homem. (STEIGLEDER, 2011, p.82).

O dano ambiental, por sua vez, representa uma lesão a bens ambientais protegidos pelo ordenamento jurídico. Para José Rubens Morato Leite (2011, p.94): 
Dano ambiental, significa, em uma primeira acepção, uma alteração indesejável ao conjunto de elementos chamados meio ambiente, como por exemplo, a poluição atmosférica; seria, assim, a lesão ao direito fundamental que todos têm de gozar e aproveitar do meio ambiente apropriado. Contudo em sua segunda conceituação, dano ambiental engloba os efeitos que esta modificação gera na saúde das pessoas e em seus interesses. (LEITE, 2011, p. 94).

As normas ambientais não definem, de forma expressa, o dano ambiental. A Lei 6.938/81 define, em seu artigo $3^{\circ}$, incisos II e III, respectivamente o que é degradação ambiental e poluição, nos seguintes termos:

Art $3^{\circ}$ - Para os fins previstos nesta Lei, entende-se por:

$[\ldots]$

II - degradação da qualidade ambiental, a alteração adversa das características do meio ambiente;

III - poluição, a degradação da qualidade ambiental resultante de atividades que direta ou indiretamente:

a) prejudiquem a saúde, a segurança e o bem-estar da população;

b) criem condições adversas às atividades sociais e econômicas;

c) afetem desfavoravelmente a biota;

d) afetem as condições estéticas ou sanitárias do meio ambiente;

e) lancem matérias ou energia em desacordo com os padrões ambientais estabelecidos;

IV - poluidor, a pessoa física ou jurídica, de direito público ou privado, responsável, direta ou indiretamente, por atividade causadora de degradação ambiental;

V - recursos ambientais: a atmosfera, as águas interiores, superficiais e subterrâneas, os estuários, o mar territorial, o solo, o subsolo, os elementos da biosfera, a fauna e a flora.

Para José Rubens Leite,

[...] pode-se concluir que o dano ambiental deve ser compreendido como toda lesão intolerável causada por qualquer ação humana (culposa ou não) ao meio ambiente, diretamente, como macrobem de interesse da coletividade, em uma concepção totalizante e, indiretamente, a terceiros, tendo em vista interesses próprios e individualizáveis e que refletem o macrobem. (LEITE, 2011, p. 104). 
Dessa forma, qualquer lesão ou ameaça ao meio ambiente, seja de forma ampla (macro bem) ou de forma específica ou individualizada (micro bem) será dano ao meio ambiente e ensejará a responsabilização do causador do dano.

\section{ARESPONSABILIDADE CIVILAMBIENTAL NAALEMANHA}

AAlemanha é um país conhecido internacionalmente por sua preocupação ambiental, sendo pioneira na adoção políticas sustentáveis. Em seu sistema legislativo, a responsabilidade por danos ambientais está prevista em algumas leis, tais como a Lei de Recursos Hídricos, Lei da Engenharia Genética, Lei da Energia Atômica, dentre outras. As duas principais normas acerca do tema são o Código CivilAlemão e a Lei de Responsabilidade CiviAmbiental.

O Código CivilAlemão (Bürgerliches Gesetzbuch - BGB), de 1900, trata da responsabilidade civil nos artigos 823 a 851 . Os artigos $823^{1}$ e $826^{2}$ trazem as normas gerais da responsabilidade civil. O BGB estabelece que a responsabilidade civil é subjetiva, pois afirma em seu artigo 823 que aquele que, intencionalmente ou por negligência, causar dano a outrem será obrigado a compensar os danos. O mesmo artigo também determina que será responsabilizado aquele que violar a lei, também de forma intencional. Pelo texto legal, nas duas hipóteses, há a exigência de culpa, caracterizando a responsabilidade subjetiva. Tais previsões se assemelham àquelas previstas no Código Civil Brasileiro, no artigo 927, caput, que traz como regra geral, a responsabilidade subjetiva.

Importante ressaltar que o texto legal alemão especifica quais direitos serão protegidos pelo instituto da responsabilidade civil, ao determinar expressamente que os danos causados à vida, ao corpo, à saúde, à liberdade, à propriedade ou outro direito individual estarão sujeitos à responsabilização. Segundo Ana Frazão (2011, p.20), "Diante desse quadro normativo, é fácil compreender porque o modelo alemão ficou conhecido pela peculiaridade de especificar os interesses prote-gidos pelas normas de responsabilidade civil”

\footnotetext{
Seção 823 - Responsabilidade por danos

(1) Uma pessoa que, intencionalmente ou por negligência, fere ilegalmente a vida, o corpo, a saúde, a liberdade, a propriedade ou outro direito de outrem deve compensar os danos causados.

(2) O mesmo dever tem a pessoa que viola a lei que se destina a proteger outra pessoa. Se a lei puder ser violada sem culpa, então a responsabilidade para a compensação só existe no caso de falha.

2 Seção 826 - danos intencionais contra a ordem pública

Uma pessoa que, de forma contrária à ordem pública, intencionalmente causa dano a outrem é responsável pela reparação do prejuízo.
} 
Já o artigo 826 impõe responsabilidade à pessoa que, de forma contrária à ordem pública, provoque, intencionalmente, danos a outrem. ParaAna Frazão (2011, p. 31) trata-se de uma cláusula residual, permitindo a responsabilização em hipóteses que não se adaptem ao artigo 823.

A responsabilidade objetiva é a exceção no direito alemão. De acordo com Roger SilvaAguar (2011, p. 143), naAlemanha, a responsabilidade objetiva só será admitida mediante norma positivada. No Código Civil Brasileiro, o parágrafo único do artigo 927, assim determina: "Haverá obrigação de reparar o dano, independentemente de culpa, nos casos especificados em lei, ou quando a atividade normalmente desenvolvida pelo autor do dano implicar , por sua natureza, risco para os direitos de outrem." Aqui também os institutos se assemelham. A norma brasileira também prevê a responsabilidade objetiva, nas hipóteses previstas expressamente em lei, assim como a norma alemã.

Há também no Código CivilAlemão, regra que determina que o vizinho prejudicado com gases, vapor odores, fumaça, fuligem, calor ruído, vibrações e influências semelhantes pode exigir uma justa indenização em dinheiro quando as perturbações não puderem ser evitadas e impedirem o uso comum do imóvel. A previsão legal, contida no artigo 906, exclui a possibilidade de indenização quando a atividade causadora do incômodo for comum no local. Aqui, mais uma vez, encontra-se dispositivo semelhante no Código Civil Brasileiro, que prevê em seu artigo 1277 que: “o proprietário ou o possuidor de um prédio tem o direito de fazer cessar as interferências prejudiciais à segurança, ao sossego e à saúde dos que o habitam, provocadas pela utilização de propriedade vizinha".

Com a evolução das discussões acerca do meio ambiente, em 1990, a Alemanha promulgou a Lei Federal de Responsabilidade Civil Ambiental (Umwelthaftungsgesetz), que de forma inovadora para a Alemanha, trouxe a responsabilidade objetiva, baseada na teoria do risco criado, para os danos ambientais. A lei trata de danos pessoais e de danos à propriedade, apresentando

\footnotetext{
3 Seção 906 Introdução de substâncias imponderáveis

(1) O proprietário de terras não pode proibir a introdução de gases, vapor, cheiros, fumaça, fuligem, calor, ruído, vibrações e influências semelhantes provenientes de outra propriedade se a influência não interfere com o uso de sua propriedade, ou interfere com ele de forma insignificante. Uma interferência insignificante é aquela que obedece aos limites legais. O mesmo se aplica aos valores administrativos gerais que foram emitidos na seção 48 da Lei de Proteção Ambiental e Impacto Federal e representam o estado da arte.

2) $\mathrm{O}$ mesmo se aplica quando a interferência é causada por uma utilização habitual no local e não pode ser evitada através de medidas que são economicamente razoável. Quando o proprietário é obrigado a tolerar uma influência nestas disposições, ele pode exigir do causador uma compensação razoável em dinheiro se a influência prejudica a utilização da trama do proprietário de terra que é habitual no local ou a sua renda além do ponto em que o proprietário pode ser esperado para tolerar
} 
um caráter predominantemente patrimonialista e privado, no qual devem ser indenizados os danos ambientais causados a pessoas certas e identificáveis.

Para Krell (1998, p.25), a indenização por dano ambiental no âmbito civil "somente pode ser reivindicada como dano individual, que atinge o direito subjetivo de uma pessoa física ou jurídica. (...) o meio ambiente por si - como bem de interesse difuso - (ainda) não é objeto de proteção jurídica-civil.'Ainda segundo o autor,

A Lei Federal de Responsabilidade CivilAmbiental (Umwelthaftungsgesetz, de 10.12.1990) (...) introduziu uma responsabilidade objetiva, baseada no risco criado, de determinadas fontes poluidoras (sobretudo instalações industriais) para danos nos "meios" ecológicos ar , solo e água. (KRELL, 1998, p. 27).

Segundo Maurício Mota (2012, p. 185), a lei alemã "estabelece uma responsabilidade que prescinde de culpa, apenas exigindo, para haver imputação, que os efeitos ambientais gerados sejam causa do dano cujo ressarcimento se pretende".

A Lei determina, já em seus $\S 1$ e $\S 2$ que, o proprietário de empreendimentos expressamente listados em um anexo, é obrigado a indenizar os particulares afetados por danos ambientais causados pela empresa, mesmo que o empreendimento ainda não esteja pronto ou que o funcionamento esteja suspenso. Segundo Andreas Joachim Krell (1998, p. 27) "A lei estabelece uma presunção de causalidade entre determinadas atividades poluidoras e o dano".

O $\S 3$ traz a definição de dano ambiental como aquele causado por substâncias, vibrações, ruído, pressão, radiação, gases, vapores, calor ou outros fenômenos que se espalharam para a terra, ar ou água, provenientes de plantas industriais, que incluem os prédios, máquinas, equipamentos, veículos e outros.

O §4 apresenta uma hipótese geral de exclusão de responsabilidade. Não há o dever de indenizar se o dano foi causado por força maiofal previsão consagra a aplicação da Teoria do Risco Criado, na qual o causador do dano pode suscitar excludentes de responsabilidade, no caso a força maiorVejamos a previsão legal:

$\S 4$ Exclusão da responsabilidade

A obrigação de indenizar não se aplica se o dano foi causado por força maior 
Já o $§ 5$ permite limitar a responsabilidade do empreendedor, nos casos em que a planta for operada como o previsto, nos moldes do $§ 6$ (todas as obrigações operacionais foram cumpridas - exigências legais, administrativas e outras).

O $\S 6$ traz a presunção de causalidade, estabelecendo que se as circunstâncias da atividade (listadas no anexo) são suscetíveis de causar o dano e ele ocorreu, presume-se que foi causado pela planta (a norma alemã denomina de planta o conjunto das instalações industriais), como se verifica no texto legal:

$\S 6$ presunção de causalidade

(1) se, de acordo com as circunstâncias individuais susceptíveis de causar o dano, uma planta for apta a causar o dano, presume-se que o dano é causado por esta planta. A adequação em casos individuais será apreciada após a operação, considerando o equipamento utilizado, o tipo e a concentração das substâncias utilizadas e liberadas, as condições meteorológicas, hora e local do acidente, o padrão de dano e todas as outras circunstâncias. $[\ldots]$

Nessas hipóteses o nexo de causalidade será presumido, não sendo necessária a sua comprovação. Porém, tal presunção não é absoluta e pode ser afastada. O próprio $\S 6$ apresenta uma hipótese em que a presunção de causalidade será afastada. Se o empreendimento funcionar de acordo com as normas estabelecidas, não há que se falar em presunção de causalidade:

$\S 6$ presunção de causalidade

(...)

(2) O parágrafo (1) não é aplicável se o equipamento foi operado como pretendido. Uma operação conforme o previsto é aquela em que os requisitos operacionais especiais foram cumpridos e não existiu falhas no funcionamento.

Além das hipóteses de força maior e funcionamento de acordo com o previsto, já citados neste estudo, também será afastada a responsabilidade do empreendedor quando existir, no caso concreto, outras circunstâncias que poderiam causar o dano (previsão que pode ser comparada à culpa exclusiva de terceiros, do direito brasileiro). Nessa hipótese, a presunção será afastada e o caso será analisado com suas particularidades, senão vejamos: 
$\S 6$ presunção de causalidade

(1) se, de acordo com as circunstâncias individuais susceptíveis de causar o dano, uma planta for apta a causar o dano, presume-se que o dano é causado por esta planta. A adequação em casos individuais será apreciada após a operação, considerando o equipamento utilizado, o tipo e a concentração das substâncias utilizadas e liberadas, as condições meteorológicas, hora e local do acidente, o padrão de dano e todas as outras circunstâncias.

(2) O parágrafo (1) não é aplicável se o equipamento foi operado como pretendido. Uma operação conforme o previsto é aquela em que os requisitos operacionais especiais foram cumpridos e não existiram falhas no funcionamento.

$[\ldots]$

De acordo com Reimund Schwarze (2001, p. 318), a cláusula de “operação normal" pareceu inicialmente representar uma redução da responsabilidade dos causadores de dano ambiental. Porém em uma análise mais aprofundada, "funcionamento normal" é definido, na própria Lei de Responsabilidade Civil Ambiental como aquele em que os requisitos operacionais são cumpridos e a operação é livre de problemas. Segundo o autor, na prática, é impossível evitar a ocorrência de falhas, logo a responsabilidade não pode ser prevenida simplesmente porque a planta funcionou da maneira prevista. $\mathrm{O}$ autor cita o exemplo dos acidentes ambientais envolvendo a empresa Hoeschst, em Frankfurt, em 1993, nos quais os peritos ambientais concordaram que os incidentes se deram em razão dos "riscos residuais", que são aqueles inevitáveis, que existem mesmo quando todas as medidas de precaução sejam tomadas.

Também o $§ 7$ determina que a presunção de causalidade será afastada quando vários empreendimentos puderem ser causadores do dano. Nesse caso, as características do dano devem ser analisadas para a determinação do responsável. Também será afastada a presunção de causalidade quando existirem, no caso concreto, outras circunstâncias causadoras de dano. De acordo com Maurício Mota (2012, p. 186). "Desse modo a presunção de causalidade apenas atua se a vítima for capaz de demonstrar que a instalação é apta, tendo em conta as circunstâncias do caso concreto, a causar o dano." Senão vejamos a previsão legal:

\footnotetext{
${ }^{4}$ Na primavera de 1993, sucessivos acidentes químicos ocorreram em fábricas de propriedade da empresa Hoechst na Área de Frankfurt, liberando no ar toneladas de uma mistura química, compostas por várias substâncias, incluindo uma cancerígena, causando contaminações na região.
} 


\section{§ 7 exclusão da presunção}

(1) Se várias plantas são aptas a causar o dano, a presunção não se aplica quando houver outro fato que possa, no caso concreto, ser o causador do dano. A aptidão para causar danos, em casos individuais, é avaliada de acordo com a hora e o local do acidente, a natureza do dano e todas as outras circunstâncias que apontam a favor ou contra ou contra a causação do dano.

(2) Se apenas uma planta é susceptível de causar o dano, a presunção não se aplica quando outra circunstância do caso concreto for susceptível de causar o dano.

De acordo com Paulo Affonso Leme Machado $(2009$, p.) o que importa é perceber que "a legislação alemã dispensou, para a presunção de autoria ou presunção de responsabilidade, que fosse estabelecido o liame de causalidade entre os atos praticados pela instalação e o dano".

A Lei de Responsabilidade Civil Ambiental Alemã prevê também que a vítima tem direito a informações prestadas pelo proprietário da fábrica, pelas autoridades e pelo proprietário da planta empresarial.Tais informações referemse aos produtos utilizados, medidas protetivas adotadas, licenças, etc. e podem ser utilizadas para embasar o pedido de indenização formulado pela vítimaAs informações podem ser recusadas ou limitadas nas hipóteses em que envolver segredo empresarial ou assuntos de interesse do Estado.

Em relação à culpa da vítima, o $\S 11$ da norma remete ao artigo $254^{5}$ do Código Civil Alemão, que por sua vez, determina que nessa hipótese, havendo culpa da vítima, a indenização será calculada considerando as circunstâncias, especialmente em que medida o dano é causado por uma parte ou por outra.

A norma também estabelece a extensão da responsabilidade, prevendo a compensação dos danos pessoais (custo de tratamentos médicos, funeral, redução laboral) e o pagamento de pensão, determinando a indenização para a vítima e seus dependentes, mesmo os nascituros, inclusive no tocante a danos morais. (§ 12 a §14). Há porém, uma limitação de valores de indenização, ao máximo de 85 milhões de euros se os danos resultam de um único impacto ambiental. (§ 15)

\footnotetext{
5 Seção 254 negligência

(1) No caso de culpa concorrente por parte da vítima, a responsabilidade por danos, bem como a extensão da indenização a ser pago dependerá das circunstâncias, em particular, e do quantum de participação das partes no dano causado.

(2) Isto também se aplica se a culpa da vítima se limita a deixar de chamar a atenção do devedor para o perigo de grandes danos, quando o devedor não tinha nem deveria ter tido conhecimento do perigo, para evitar ou reduzir os danos. A prestação de secção 278 aplica-se com as modificações necessárias.
} 
Em seu §16, ao regulamentar os gastos com a recomposição do meio ambiente degradado, remete ao artigo 251, $\S 2^{\circ}$ do Código CivilAlemão ${ }^{6}$, que determina que quando as despesas com a restauração forem desproporcionais ao valor da coisa, a restauração deve ser substituída por uma indenização em dinheiro.

A lei exige que os proprietários de empreendimentos cujas atividades estejam listadas no Anexo 2 possuam "segurança financeira", ou seja, exige que seja garantida a possibilidade econômica de cumprir as obrigações de ressarcimento de danos decorrentes de impacto ambiental. Tal garantia pode ser implementada através de seguro de responsabilidade civil.

Importante ressaltar que a lei trata aqui de Seguro de Responsabilidade Civil, de forma geral, não se tratando no caso, de SegurAmbiental. Como a lei em análise trata de danos causados a particulares, os seguros terão por objetivo o ressarcimento dos danos causados a estes particulares, e não ao meio ambiente.

A LeiAlemã estabelece ainda que os prazos prescricionais são os mesmos previstos no Código Civil Alemão e prevê sanções pelo descumprimento das previsões legais. Além disso, expressamente exclui sua aplicação para as hipóteses de acidente nuclear (aplica-se a Lei de Energia Atômica, com suas alterações).

Segundo Andreas Joachim Krell (1998, p. 27), a Lei Federal de Responsabilidade CivilAmbiental Alemã "tem por objetivo melhorar a situação jurídica de pessoas que sofreram um dano individual em virtude de poluição ambiental." Para o autor , a lei, ao trazer a responsabilidade objetiva para determinadas atividades, avançou em relação ao Código Civil Alemão, pois com a nova legislação, as vítimas de dano ambiental estarão dispensadas da comprovação do nexo causal.

Em 2007, visando ampliar a proteção ao Meio Ambiente, o Parlamento Alemão aprovou a Lei de Desastre Ambiental (Umweltschadensgesetz UschG), para implementar a Diretiva 2004/35/EC ${ }^{7}$ do Parlamento Europeu e

\footnotetext{
${ }^{6}$ Seção 251. Danos em dinheiro sem a especificação de um período de tempo

(1) Na medida em que a recuperação não é possível ou não é suficiente para compensar o credor, o devedor deve compensar o credor em dinheiro.

(2) A pessoa responsável por danos causados pode compensar o credor em dinheiro se a restauração só é possível com despesas desproporcionais. As despesas incorridas como resultado do tratamento curativo de um animal ferido não são desproporcionais simplesmente porque excedem significativamente o valor do animal.

7 A Diretiva 2004/35/CE foi aprovada pelo Parlamento Europeu e Pelo Conselho, em 21 de abril de 2004 e tem por objetivo estabelecer um quadro de responsabilidade ambiental baseado no princípio do poluidor-pagador para prevenir e reparar danos ambientais.
} 
do Conselho. Segundo Hogan e Hartson (2007, p. 1), essa lei pretende sanar brechas de responsabilidade existentes no direito alemão. Para os autores, em regra geral, as normas alemãs relativas à responsabilidade por dano ambiental "exigem que o dano ocorra em bens que são propriedade de outras empresas, indivíduos ou do Estado. Na visão do legislador danos a bens jurídicos de domínio público (por exemplo, animais, plantas, água, solo, etc.) foram mal compreendidas até agora" (HOGAN E HAR TSON, 2007, p.1)

A nova lei de danos ambientais não pretende substituir as demais normas existentes, mas sim complementá-las. Com ela, alguns conceitos são apresentados. $\mathrm{O} \S 2$ traz algumas definições, dentre elas, o conceito de dano ambiental, passível de responsabilização, que foi ampliado, passando a incluir também os danos causados às espécies e habitats naturais, à água e ao solo. Percebe-se que a preocupação deixa de ser apenas patrimonial para se tornar também ambiental. Apresenta também o conceito de Responsável, como qualquer pessoa, individual ou coletiva, que se dedica ou controla uma atividade, incluindo aqueles que possuem licença ou autorização, ou que notifiquem ou registrem a atividade.

Os danos ambientais passíveis de responsabilização são os causados por profissões ou atividades listadas em um anexo, para as quais a responsabilidade é objetiva. Porém nos danos causados às espécies ou habitats naturais, se o causador do dano agiu com culpa ou negligência será responsabilizado, mesmo que sua atividade não conste do anexo legal (responsabilidade subjetiva).

Importante ressaltar que a lei prevê, expressamente em seu $\S 3$ que sua aplicação será apenas nos casos em que o dano ambiental seja causado por poluição difusa, onde seja possível estabelecer o nexo de causalidade entre os danos e as atividades desenvolvidas. Percebe-se, dessa forma, que a responsabilidade é objetiva, pela te oria do risco criado, uma vez que não se discute a culpa do empreendedor, mas tão somente a ocorrência do dano e nexo causal. De acordo com essa norma, a responsabilidade somente será subjetiva quando houver dano às espécies ou habitats naturais, quando o agente somente será responsabilizado se agir com culpa ou negligência.

O novo diploma legal, que entrou em vigor em novembro de 2007 prevê, em seu $\S 4$ que os responsáveis por atividades de risco têm o dever de informar imediatamente às autoridades acerca de qualquer perigo de danos ambientais, assim como dos danos já ocorridos. Também têm o dever de evitar o perigo, através da adoção de medidas preventivas (§ 5). 
Na hipótese de ocorrência de dano ambiental, os responsáveis devem tomar medidas para controlar e corrigir os danos ( $\S \S 5$ e 6 ), de acordo com as determinações da autoridade competente. (§8). Os custos com as medidas preventivas e corretivas devem ser suportados pelos responsáveis pelo dano, que podem reivindicar compensações entre si (ação de regresso)

A norma não se aplica aos danos causados por conflitos armados, caso fortuito ou força maior, atividades nucleares (regulamentadas por Tratados Internacionais), e atividades abrangidas pelo Tratado De Energia Atômica da União Européia. (§3)

No Brasil, a responsabilidade civil por dano ambiental não está prevista em normas específicas, como na Alemanha. As previsões se encontram na Constituição Federal e na Lei da Polí tica Nacional do Meio Ambiente. O ordenamento jurídico brasileiro adota a responsabilidade civil objetiva. $\mathrm{Na}$ Constituição Federal, a responsabilidade é tratada no artigo 225:

Art. 225. Todos têm direito ao meio ambiente ecologicamente equilibrado, bem de uso comum do povo e essencial à sadia qualidade de vida, impondose ao Poder Público e à coletividade o dever de defendê-lo e preservá- lo para as presentes e futuras gerações. (...)

$\S 3^{\circ}$ - As condutas e atividades consideradas lesivas ao meio ambiente sujeitarão os infratores, pessoas físicas ou jurídicas, a sanções penais e administrativas, independentemente da obrigação de reparar os danos causados.

De acordo com CelsoAntonio Pacheco Fiorillo (2006, p.47-48):

Como foi destacado, a responsabilidade civil pelos danos causados ao meio ambiente é do tipoobjetiva, em decorrência de o art. $225, \S 3^{\circ}$, da Constituição Federal preceituar a "...obrigação de reparar os danos causados" ao meio ambiente, sem exigir qualquer elemento subjetivo para a configuração da responsabilidade civil.

Ainda de acordo com o autor:

“O art. 225, $\S 3^{\circ}$, da Constituição Federal previu a tríplice penalização do poluidor (tanto pessoa física como jurídica) do meio ambiente: a sanção penal, por conta da chamada responsabilidade penal, a sanção administrativa, em decorrência da denominada responsabilidade administrativa, e a sanção civil, em razão da responsabilidade civil”. (FIORILLO, 2006, p.46) 
Também a Lei de Política Nacional do Meio Ambiente traz previsão de responsabilidade civil objetiva, senão vejamos:

Art 14

$[\ldots]$

$\S 1^{\circ}$ - Sem obstar a aplicação das penalidades previstas neste artigo, é o poluidor obrigado, independentemente da existência de culpa, a indenizar ou reparar os danos causados ao meio ambiente e a terceiros, afetados por sua atividade. O Ministério Público da União e dos Estados terá legitimidade para propor ação de responsabilidade civil e criminal, por danos causados ao meio ambiente. (grifo nosso)

No Brasil, a doutrina e jurisprudência majoritárias defendem, para as hipóteses de dano ambiental, a responsabilidade objetiva, adotando a teoria do risco integral.

Para Édis Milaré (2005, p. 827):

A vinculação da responsabilidade objetiva àteoria do risco integral expressa a preocupação da doutrina em estabelecer um sistema de responsabilidade o mais rigoroso possível, ante o alarmante quadro de degradação que se assiste não só no Brasil, mas em todo o mundo. Segundo a teoria dorisco integral, qualquer fato, culposo ou não-culposo, impõe ao agente a reparação, desde que cause um dano.

Já para José Alfredo Baracho Júnior (2000, p. 322):

A vinculação da responsabilidadeobjetiva à teoria do risco integral expressa a grande preocupação dos doutrinadores brasileiros em estabelecer um sistema de responsabilidade o mais rigoroso possível, o que se justifica em face do alarmante quadro de degradação existente no Brasil.

Ainda nesse sentido, Herman Benjamin (p. 123):

Espelhando-se no tratamento dado aos acidentes do trabalho e levando em conta o perfil constitucional do bem jurídico tutelado - o meio ambiente, direito de todos, inclusive das gerações futuras, de fruição comum do povo, essencial à sadia qualidade de vida, e por isso mesmo, de preservação assegurada, é que o sistema jurídico ambiental adota a modalidade mais rigorosa de responsabilização civil, aquela, que dispensa a prova de culpa. 
Também pelas mesmas razões, o Direito Ambiental Nacional não aceita as excludentes do fato de terceiro, de culpa concorrente da vtíma (que vítima, quando o meio ambiente tem como titular a coletividade?) e do caso fortuito e forç a maior. Se o evento oc orreu no curso ou em razã o de atividade potencialmente degradadora, incumbe ao responsável por ela reparar eventuais danos causados, ressalvada sempre a hipótese de ação regressiva.

Dessa forma, $\mathrm{n}$ a responsabilidade civil ambiental, as normas alemã e brasileira se assemelham ao adotarem a responsabilidade objetiva, porém diferenciam-se pela teoria adotada. Enquanto naAlemanha a opção do legislador foi pela teoria do risco criado, no Brasil optou-se pela teoria do risco integral.

\section{CONSIDERAÇÕES FINAIS}

Dos estudos realizados, pode-se concluir que as normas alemãs acerca de responsabilidade civil ambiental são concisas e se baseiam, em regra, na teoria da responsabilidade subjetiva, exigindo a comprovação da culpa do agente. As principais exceções podem ser verificadas na Lei de Responsabilidade Civil Ambiental, de 1990 e na Lei de DesastresAmbientais, de 2007, que trouxeram uma significativa alteração, prevendo a responsabilidade objetiva, pela teria do risco criado, para as atividades elencadas pelo próprio diploma legislativo.

O principal objetivo da Lei de Responsabilidade CiviAmbiental Alemã é garantir que as vítimas de danos ambientais sejam indenizadas pelos danos sofridos. Nas hipóteses listadas pela lei, ocorrendo o dano, há a presunção de causalidade, levando à responsabilidade do empreendedor Importante ressaltar que tal presunção é apenas relativa, uma vez que a ocorrência de força maior, assim como a "regularidade" da atividade podem afastar a presunção.

De forma expressa, o legislador alemão optou pela teoria do risco criado, uma vez que as atividades consideradas de risco serão responsabilizadas objetivamente, porém o causador do dano poderá alegar excludentes de responsabilidade para se eximir da indenização. É possível a alegação de força maior, que ensejará a exclusão de responsabilidadeTambém podem ser alegados o "funcionamento conforme o previsto" e a existência de outras circunstâncias que poderiam causar o dano, hipóteses em que a presunção de causalidade fica afastada, devendo o nexo de causalidade ser comprovado no caso concreto.

Outro aspecto importante é a prioridade que a norma dá à compensação do dano causado. Não há uma intenção punitiva na aplicação da responsabilização civil, mas tão somente a preocupação de compensar a vítima 
pelos danos sofridos, limitando-se, na maioria das vezes, a ressarcir danos pessoais ou perda da propriedade. Por essa razão, os empreendedores devem garantir "segurança financeira", ou seja, devem comprovar que possuem capacidade econômica para arcar com eventuais indenizações por dano ambiental, o que pode ser cumprido através de seguros de responsabilidade civil, prática comum nos países europeus.

As leis alemãs visam assegurar a compensaçã o individual por danos ambientais, estabelecendo normas que visam facilitar a situação da vítima de impacto ambiental, que não precisa comprovar o nexo causal, ao menos nas hipóteses de danos causados por empresas cujas atividades estejam elencadas no anexo 1 da Lei de Responsabilidade CiviAmbiental.

Já a Lei dos Desastres Ambientais, de 2007, avançou em relação à preocupação com o meio ambiente. Nessa legislação, a preocupação deixa de ser com os prejuízos individuais ou particulares e passa a ser com a proteção do meio ambiente.

Aqui também a lei determina que a responsabilidade será objetiva para as atividades listadas, responsabilizando os empreendedores por danos causados às espécies e habitats naturais, à água e ao solo. Os empreendedores cujas atividades estão listadas na lei Têm a obrigação de implementar medidas para prevenção de danos ao meio ambiente.

Na hipótese de dano ambiental, o responsável deverá arcar com as despesas com medidas para controlar os danos e para recuperar o ambiente degradado.

Em ambos os diplomas legais, verifica-se a preocupação com a informação. Os empreendedores têm a obrigação de prestar informações aos interessados acerca das atividades desenvolvidas e dos danos causados, o que, sem dúvida, irá facilitar as medidas para compensação dos danos causados.

Também a adoção da responsabilidade objetiva e da presunção de nexo causal têm por objetivo tornar mais fácil para a vítima do dano ambiental a persecução de seus direitos.

Em relação ao aspecto educativo ou preventivo da responsabilização por dano ambiental, as normas alemãs deixam muito a desejar, uma vez que não impõem aos poluidores sanções que possam desestimular novos danos ambientais.

O que se pode concluir é que o legislador alemão optou, em regra geral, pela responsabilidade civil objetiva para as hipóteses de dano ambiental, o que se deu de forma expressa na Lei de Responsabilidade CiviAmbiental de 1990 
e na Lei deDesastres Ambientais, de 2007. O legislador optou ainda pela teoria do risco criado, uma vez que permitiu a alegação de excludentes de responsabilidade.

\section{REFERÊNCIAS}

AGUIAR, Roger Silva. Responsabilidade Civil. São Paulo. Atlas. 2011

ALEMANHA, German Civil Code. 2002

ALEMANHA, Umwelthaftungsgesetz vom 10. Dezember 1990

ALEMANHA, Umweltschadensgesetz - UschG 10. May 2007

AMORIM, Paulo Henrique. A responsabilidade civil do estado decorrente de danos ocasionados por fenômenos da natureza. 2011. Disponível em http://www.egov.ufsc.br/portal/sites/default/files/anexos/54155407-1-PB.htm. Acesso em 01 out 2014.

BARACHO JÚNIOR, José Alfredo de Oliveira. Responsabilidade civil por dano ao meio ambiente. Belo Horizonte: Del Rey, 2000. 340 p.

BENJAMIN, AH de V.; Responsabilidade Civil pelo dano ambiental. Disponível em http://migre.me/mmfMg.Acesso em 01 out 2014

BRASIL. Constituição (1988). Constituição da República Federativa do Brasil. 1988. Brasília: Senado Federal . Lei n. ${ }^{\circ} 6.938$ de 31 de agosto de 1981.

BEDRAN, Karina Marcos. MA YER, Elizabeth. A responsabilidade civil por danos ambientais no direito brasileiro e comparado: Teoria do risco criado versus teoria do risco integral. In Revista V eredas do Direito. Belo Horizonte, v. 10, n. 19, p. 45-88. Janeiro/junho 2013. Disponível em http://www.domhelder.edu.br/revista/index.php/veredas/article/view/271/ 339. Acesso em 14 set 2014. 
CAVALIERI FILHO, Sér gio. Programa de responsabilidade civil. 9 ed. São Paulo: Atlas, 2010.

DINIZ, Maria Helena. Curso de Direito Civil Brasileiro, volume 7, $27^{\mathrm{a}}$ ed. São Paulo: Saraiva, 2013.

FIORILlo, Celso Antonio Pacheco. Curso de Direito Ambiental brasileiro. 7. ed. São Paulo: Saraiva, 2006.

FRAZÃO, Ana. Pressupostos e funções da responsabilidade civil subjetiva na atualidade: um exame a partir do direito comparado. Revista do Tribunal Superior do Trabalho, São Paulo, v. 77, n. 4, p. 17-43, out./dez. 2011. Disponível em http:/aplicacao.tst.jus.br/dspace/handle/1939/ 28339. Acesso em 10 set 2014.

GONÇALVES, Carlos Roberto. Direito civil brasileiro. 3. ed. rev . e atual. São Paulo: Saraiva, 2008. v. IV.

HOGAN \& HARTSON. Enviromental update. 2007. Disponível em http:// migre.me/mmaVI Acesso em 15 ago 2014.

KRELL, Andreas Joachim. Concretização do dano ambiental. Algumas objeções à teoria do "risco integral”. In Revista de Informação Legislativa, n. 139, Brasilia, Jul/set 1998. Disponível em http:// www.buscalegis.ufsc.br/revistas/files/anexos/6820-6819-1-PB.html. Acesso em 10 set 2014 .

MACHADO, Paulo Afonso Leme. Direito Ambiental Brasileiro. 17 ed., rev., atual. e ampl. São Paulo, Malheiros, 2009.

MILARÉ, Édis. Direito do ambiente: Doutrina - Jurisprudência Glossário. 4. ed. São Paulo: Revista dos Tribunais, 2005.

MOTA, Mauricio. Pressupostos da Responsabilidade Civil do Estado por Danos ao Meio Ambiente. Revista de Direito da Cidade, v . 4, n. 2, p. 166-192, 2012. Disponível em http://wwwe-publicacoes.uerj.br/index.php/ rdc/article/view/9716. Acesso em 06 ago 2014. 
PEREIRA, Caio Mário da Silva. Responsabilidade Civil. $3^{a}$ Ed. Rio de Janeiro: Forense, 1992

SCHWARZE. Reimund. Environmental liability and accident prevention: preliminary experiences in Germany. Journal Article European Environment. 2001. Disponível em http://phdtree.org/pdf/ 30216965-environmental-liability-and-accident-prevention-preliminaryexperiences-in-germany/ Acesso em 01 set 2014.

STEIGLEDER, Annelise Monteiro. Responsabilidade civil ambiental: as dimensões do dano ambiental no direito brasileiro. 2 ed. V er. Atual. E ampl. - Porto Alegre: Livraria doAdvogado Editora, 2011.

STOCO, Rui. Tratado de responsabilidade civil: doutrina e jurisprudência. 8 ed.. São Paulo Editora Revista dos Tribunais, 2011.

SOUZA, Carlos Aurélio Mota de. Direito Ambiental. ARAÙJO, Gisele Ferreira de. (org) São Paulo. Ed. Atlas, 2008. German Civil Code - BGB.

Artigo recebido em: 18/11/2014 Aprovado para publicação em: 10/08/2015

Como citar: CORREIO, Daniela Oliveira Gonçalves. REZENDE, Élcio Nacur Responsabilidade civil ambiental na Alemanha: um estudo comparativo com o direito brasileiro. Revista do Direito Público. Londrina, v10, n.2, p.3964, mai./ago. 2015. DOI: 10.5433/1980-511X.2015v10n2p39. 